\title{
PROTECTION OF WATER BASED AND WATER ABSTRACTION SITES IN HUNGARY BASED ON STUDIES IN GYÖR
}

\section{VÍZBÁZISOK ÉS VÍZKIVÉTELI HELYEK VÉDELMÉNEK MEGVALÓSULÁSA MAGYARORSZÁGON GYÖRI VIZSGÁLATOK ALAPJÁN}

\author{
TAKÁCS Krisztina \\ (ORCID: 0000-0002-9481-814X) \\ takacs.krisztina@uni-nke.hu
}

\begin{abstract}
Water is indispensable for life and social activity, the most widely used on Earth. Today, an increasing problem is the production of sufficient quantity and quality of potable water for mankind. In order to ensure the supply of water, nowadays we must pay special attention, since it is intended to provide the consumer with adequate quality and quantity of water from a public health point of view. This also includes proper protection of water bases, which prevents any harmful substances or dirt from entering the water. Potable water supply is a special task, since in all circumstances it is necessary to ensure the smooth operation of the population. For this activity, maximum protection of the water bases and the water supply system is essential, which I will examine for Hungary, and I will also present a practical example.

"This article was prepared by the Ministry of Human Resources with the support of New National Excellence Program UNKP-18-3-INKE-105"
\end{abstract}

Keywords: water base, water base protection, water-conduit, sampling, potable water

\begin{abstract}
Absztrakt
A víz az élet, a társadalmi tevékenység számára nélkülözhetetlen, a Földön a legszélesebb körben használt vegyület. Napjainkban egyre nagyobb problémát jelent az emberiség számára szükséges megfelelö mennyiségü és minőségű ivóvíz előállítása. $A$ vízellátás biztositására napjainkban is kiemelt figyelmet kell fordítanunk, hiszen ennek célja, hogy a fogyasztóhoz közegészségügyi szempontból megfelelö minőségü és mennyiségü víz kerüljön. Ehhez hozzátartozik a vízbázisok, illetve a vízkivételi helyek megfelelö védelme is, amely megakadályozza, hogy bárminemü káros anyag, szennyezödés kerüljön a vízbe. $A z$ ivóvízellátás egy speciális feladat, ugyanis minden körülmények között biztosítani kell a megfelelö minőségü ivóvizet a lakosság számára. Ehhez a tevékenységhez elengedhetetlen a vízbázisok és a vízellátó rendszer maximális védelme, amelyet Magyarország tekintetében vizsgálok, valamint gyakorlati példát is bemutatok.

„A cikk az Emberi Eröforrások Minisztériuma ÚNKP-18-3-I-NKE-105 kódszámú Új Nemzeti Kiválóság Programjának támogatásával készült"
\end{abstract}

Kulcsszavak: vízbázis, vízbázis-védelem, vízkivételi hely, mintavétel, ivóvíz 


\section{INTRODUCTION}

In present advanced world, the basic criterion for ensuring that water supply is maintained in all conditions is not unexpected events that could prevent it.

The primary objective of water base protection is to deliver drinking water of sufficient quantity and quality to consumers. The first step in this process is to find a suitable water base or water resource. There is no unified regulation for the protection of water bases, so it is the responsibility of the operator of the water bases to protect the water base from any threatening factors.

Water can also be recovered in several ways, however, in order for the recovered water to be suitable for human consumption or to comply with the limits prescribed by the relevant legislation, water treatment and water purification procedures should be used in most cases. This purified water reaches the consumer through distribution networks. This process is quite vulnerable, because if there is a problem at any point in the water supply, it can affect the quality of the end product, that is the drinking water. That is why we must pay special attention to the protection of water basins and water abstraction sites.

Most of the literature discusses the above-mentioned topics separately, but in my present paper, however, I examine the topic in a complex way and the problems that may arise.

In my writing I present the water bases occurring in Hungary, I deal with the concept of sustainable water management, introduce the drinking water supply as a critical infrastructure element. I deal with legal regulation of water base protection. I also say about the vulnerability of water intake sites and the importance of sampling. I present the hazards of biological origin occurring during the extraction of drinking water. The aim of this article was to draw attention to the importance of potable water supply.

\section{CHARACTERISTICS OF HUNGARIAN WATER BASES}

As a first step, I consider it important to present the most important characteristics of water bases in Hungary. In later, I am going to detail what types of protection levels belong to different water bases.

Our country is in a fortunate position as its water resources are abundant. In potable water supply, the same quality of raw water should be produced equally from raw water of different quality. First of all, we need to get good quality raw water for potable water. In Hungary, the production of raw water is possible from four types of water bases:

\section{Underground protected layers}

$95 \%$ of our planet's underground water resources are structurally bound in underground rocks and minerals, and this is not seen as part of the water resource. From an environmental point of view, only the underground water body is considered to be groundwater, which in the soil and in the clay is structurally unconnected, but in the form of liquid particles, possibly in the form of steam, between the material particles.[1] We have access to underground water resources through strictly guarded closed-loop wells. The depth of wells can range from ten meters to hundreds of meters.

\section{Riverside gravel bed}

From a pebble bed, also known as a beach-filtered water base. In the case of the production of shore-filtered water, we mainly use surface water. They are usually cleaned only by the waterconducting rocks, such as gravel, gravel, sand, which are in contact with them. Here is the name of the Coastal Screening. At the national level, a significant part of the public water supply, about $40 \%$, is obtained from shore-filtered wells. However, the water base is 
vulnerable due to its position and therefore needs more protection. [2] An excellent example of a shore-filtered water base is the thick gravel layer along the Danube, which acts as a physical and biological filter. Thanks to this, a shallow depth (10-25 m deep) wells and so-called wells near the river bed can be found. tent wells provide water from drinking water quality, supported by a large number of laboratory tests.

\section{Limestone, dolomite mountains karst}

Limestone, karst of dolomite mountains. The karst water is the one that is stored and moving in the cavity and flight systems of carbonate rocks released by the carbonated water, and in the fissure and cracking network formed by mountain structure pressure or movements. The surface is partly infiltrated, partly through the sinkholes to the rivers and passages of the mountains. The accumulation of karst water flows through the valleys to the surface through a constant or intermittent karst source. The karst water set is a reservoir of water of very variable cracks, fissures, and flights of carbonate rocks (limestone, dolomite). The karst reservoirs sometimes reach the surface and are uncovered from the top (open karst), while others are covered from above (covered karst). Open karst is unprotected against surface contamination. The hardness of karst waters is high, the water is only cloudy during major rains, otherwise it is clean and tasty, usually suitable for drinking.[3] Such limestone and dolomite mountains in Hungary are Bakony, Vértes, and Bükk.

\section{Surface waters}

Rivers, lakes and artificial reservoirs, as well as sea waters, form a group of surface waters. The water from the streams and rivers is made up of rainwater collecting on the surface, leaking from the soil and artificially highlighted water. River water usually contains fewer dissolved salts in well water, but much more floating substances, such as mineral, vegetable and industrial contaminants. The bacterial content of the rivers is able to oxidise the organic pollutants that flow into the rivers: this allows the self-cleaning of the rivers. [4]

In Hungary, $98 \%$ of the total water supply comes from groundwater, as these stocks are practically present, exploitable and generally less polluted throughout the country, making their cleaning more economical.[5] This ratio is also in line with the recommendation of the World Health Organization to WHO municipalities. On this basis, household drinking water needs should, as far as possible, be met by groundwater resources, as they are less susceptible to pollution-related pollution than surface waters, their quantity and quality are more uniform and generally require much less water treatment technologies.

Surface water, however in much larger quantities than groundwater, is only used in areas where potable water supply would not otherwise be possible. This is because surface water is directly exposed to contaminants, making cleaning more expensive.[6] In Hungary, we get surface water from many artificial reservoirs in the Tisza (eg Szolnok), Bükk and Mátra, and from Lake Balaton.

In addition, it should also be mentioned that the elimination of pollution, rehabilitation of contaminated groundwater bases is much more difficult, costly and time consuming than for surface waters.

Although groundwater is indeed much more protected than the surface due to the geological formations above it, it does not mean complete safety. Some groundwater basins are particularly vulnerable, which means that there is no thick layer of water or a barrier that prevents surface contaminants from leaking into the aquifer and causing them to appear in the extracted water sooner or later. 
The most common sources of groundwater contamination are non-sewage settlements, excessive use of agricultural chemicals, livestock farms, inadequate waste disposal, oil and fuel storage, military and industrial facilities, surface and underground mining.

\section{SUSTAINABLE WATER MANAGEMENT}

The protection of water resources has always been an important aspiration for the states, and it is no different nowadays. According to the results of the WHO and UNICEF Joint Monitoring Program (JMP) surveys, in 2008, 884 million people did not have access to adequate drinking water quality and 2.6 billion people lacked adequate sanitation. The emerging conflict situation warns that global water resource management should not violate the principles proclaimed in 1948 in the Water Charter (Council of Europe, 6 May 1948). Inadequate use of the water resources available in limited quantities poses a threat to the environment and to sustainable development. This recognition has led different countries to create water protection conventions and legislation. They are very diverse. An overview of the 17 major water management and water-related international and national water agreements is included in the Water Charter 12. [7]

The basic rules of water management are laid down in the LVII of 1995 on water management. law. It lays the foundations for a general state and municipal activity system for protecting the environment. Determines the structure of the environmental management system and the responsibility of society as a whole through the responsibility of individuals to protect their environment.[8] In the field of water management, we should also mention the protection of water bases, as this, among other things, contributes to the development of safe drinking water supply.

Efforts should be made for both industrial and residential water users for sustainable water management. It is also necessary to adapt to the effects of global climate change on water management and water use.[9] In the following, I will examine these issues.

\section{WATER SUPPLY AS THE CRITICAL INFRASTRUCTURE ELEMENT}

Critical infrastructures refer to a network of interconnected, interactive and interdependent infrastructure elements, facilities, services, systems and processes that are vital to the functioning of the country (population, economy and government) and have a meaningful minimum level of legal certainty. , public security, national security, economic operability, public health and the environment. Critical infrastructures are those networks, resources, services, products, physical or information technology systems, equipment, devices and their constituent parts, whose malfunction, disruption, loss or destruction may have a direct or indirect, temporary or long-term impact on the economic, social welfare, public health, public security, national security, the national economy and government.[10]

Drinking water service is provided by Decree 2080/2008 on the National Program for Critical Infrastructure Protection. (VI. 30.) Governmental Critical Infrastructure (Sector IV), the protection of which, inter alia, is the responsibility of the public utility operator. It also deals with the protection of water bases in this sector in detail.

\section{LEGAL REGULATION OF WATER BASEE PROTECTION}

In the last decade, the concept of water base protection has become more and more publicly known, one of the signs that the importance of water resources for drinking water has increased throughout the world. Economic and social analyzes consider the issue of drinking water as one of the key factors in the development of decades and centuries. The concept of water base was first mentioned in the LVII of 1995 on water management. law. Waterbase: 
Area or sub-surface area used by, or designated for, water abstraction facilities and water resources extracted therefrom with existing or planned water supply facilities.[8]

The legal bases for the legal regulation of water bases are the 123/1997 on the protection of water bases, water bases and water supply facilities. (VII. 18.) Government Decree.

There are two types of water bases in it. On the one hand, the existing water bases that meet current needs and on the other, the long-term water bases that will provide future drinking water supply. These are areas that have good water-carrying capacity and will be used as a water extraction plant in the future.[11]

In the wording of Government Decree 123/1997. (VII. 18.), the designation is based on the time of reaching the presumed contamination to a given water production site:

- internal protection zone (water intake and direct protection of water resources from contamination and damage) - 20 day access time,

- external protection zone (non-decomposing, protection against bacterial and other degradable contamination) - 6 months access time,

- hydrogeological zone A, zone B protective dams (protection against dangerous pollution of different danger) - access times: 5 years, 50 years.

Each zone has a different function, but overall it serves the same purpose of preventing and limiting existing and future polluting activities to varying degrees. Protective areas are intersections with protective surfaces with the surface. Geologically protected (nonvulnerable) water basins have only a protective dome, but according to the law, a minimum $10 \mathrm{~m}$ radius of internal protection is required at this time. In order to ensure strict protection around the production wells, the internal defense areas are always owned by the state or the local government. In other areas of protection, the owner of the property is obliged to comply with the Protected Area Decision and carry out his activities taking into account the aspects of water base protection. The process of designating defenses and protective areas ends with the issuing of an official decision and, as a consequence, the land registry entry.[12]

\section{OWN TESTS, SAMPLING}

In addition to water basins, water abstraction sites should also be mentioned, as their protection also plays a role in providing adequate drinking water. The quality of the drinking water provided must be checked regularly, in accordance with the legislation, for the required chemical, microbiological and microscopic biological parameters. The number of samples to be taken each year depends on the number of inhabitants of the settlement and the amount of water supplied. The waterworks operator must ensure that the quality of drinking water is checked in an accredited laboratory for drinking water testing. In addition, the authorities' laboratories conduct water tests in the municipalities. The minimum sampling and testing frequency, which is determined on the basis of the amount of water supplied or the number of inhabitants, is set out in 201/2001. Annex 2 to Government Decree. In some parts of Györ, an average of 4 samples per year are taken by the local water company, where a control test is carried out. The purpose of this is to provide regular information on the organoleptic and microbiological quality of drinking water for human consumption, on certain chemical water quality characteristics, on changes in water quality, and on the effectiveness of water treatment. The following parameters are checked during the test: color odor, taste, turbidity, $\mathrm{pH}$, conductivity, Esherichia coli, Coliform bacteria, colony count at $22^{\circ} \mathrm{C}$ and $37^{\circ} \mathrm{C}$. In addition to the inspection test, a detailed inspection should be carried out once a year to determine whether the drinking water meets all the requirements of the Regulation.[13]

Sampling takes place on the one hand at water abstraction points and on the other hand at designated consumer points, which may be public drains, faucets, public toilets, wells. Samples to be tested are taken by a designated sample person who is regularly trained. For 
bacteriological testing, it is important to flush the water outlet, such as the pin of the tap, to prevent external impurities from getting into the water. We open the tap and then let the water in sterile glass after a few minutes. The samples are then shipped to the accredited Quality Control Laboratory as soon as possible, where the required microbiological tests are performed.

If a sample exceeds a value, the provider will take the necessary measures to improve the water quality, for example, by the competent authority or by the health authority. chlorination, and then sampling as necessary, should be repeated to ensure that the measured values are within the limit.

The human factor plays the major role in the proper implementation of sampling. There are a number of rules that need to be followed to get a real result when examining a sample.

\section{SAMPLING FREQUENCY, RESULTS}

In connection with this study, from January 2018 to November 2018, the microbiological test results of the samples taken from designated sampling sites will be presented at regular intervals in order to monitor water quality. In the examined period, a total of 165 samples were taken by Pannon-Víz Zrt., Of which 561 bacteriological tests were performed. I also took part in the examination of the samples. The results of the examined samples are summarized in Table 1.

201/2001. (X. 25.) Government Decree No. 1, item A, microbiological water quality characteristics include E. coli, Entorococcus, Pseudomonas aeruginosa, colony number at $22^{\circ}$ $\mathrm{C}$ and $37^{\circ} \mathrm{C}$. According to point $\mathrm{A}$, the sample is objectionable if the water is inadequate, contains various microorganisms, substances that endanger human health. Point $\mathrm{C}$ of the Decree includes water quality characteristics such as Clostridium perfringens, Pseudomonas aeruginosa, Coliform bacteria, total germ, $\mathrm{pH}$, iron and manganese content, color, taste, turbidity. This primarily has a control role, so this water does not contain any substance that endangers human health, it does not present a direct public health hazard, but it may also contain substances that interfere with water use (such as aesthetic or other complaints), or socalled indicator bacteria.

The samples examined show that none of the samples complained of under "A" was in the year 2018; E. coli in the water. Inadequate samples were most often based on the presence of high colony count, Coliform, and Pseudomonas aeruginosa. Taking into account the data of the last 1 year, it can be stated that during this time there were very few problems with drinking water compared to the number of samples taken and the microbiological tests performed.

\begin{tabular}{|c|c|c|c|c|}
\hline $\begin{array}{c}\text { Place of } \\
\text { sampling }\end{array}$ & $\begin{array}{c}\text { Number of } \\
\text { samples } \\
(\mathrm{db})\end{array}$ & $\begin{array}{c}\text { Number of } \\
\text { bacteriological } \\
\text { tests }(\mathrm{db})\end{array}$ & $\begin{array}{c}\text { Number of samples } \\
\text { objected to under } \\
\text { "A" (db) }\end{array}$ & $\begin{array}{c}\text { Number of } \\
\text { samples objected } \\
\text { to under "C" (db) }\end{array}$ \\
\hline Györ & 165 & 561 & 0 & 6 \\
\hline
\end{tabular}

Table 1 Number of samples taken in the area of Györ (compilation of the author based on the data of Pannon-Víz Zrt.)

Many have been dealing with the physical protection of water bases, so I would like to say a few words about the biological hazards that threaten water bases. 


\section{OCCURRENCE OF HAZARD ON THE WATER BASES}

Examining the types of water pollution and the most frequent threats to water bases, it can be stated that infections are usually caused by biological threats, such as bacteria, viruses, protozoa, fungi, worms.

Water-borne infections are mainly due to diarrhea, vomiting and high fever, but there may be other symptoms. Such infections usually affect not just one person. In many cases epidemics can develop.[14]

In the case of biological risks, one of the biggest sources of water pollution, industry, including the chemical industry, the food industry and light industry, is the most problematic. In fact, wastewater is often discharged into surface waters without prior purification, which is more dangerous than communal wastewater, since it contains a large amount of organic and mineral contaminants, and even toxic substances are present. In fact, communal wastewater is the used water of settlements. In this organic substances, proteins, fats, carbohydrates are most commonly found. In addition, it should be mentioned that biological contaminants are also present, including viruses (eg Hepatitis A, Norwalk virus) or bacteria (eg Escherichia Coli, other coliform bacteria).[4]

\section{Bacteria}

Certain types of bacteria can lead to deterioration in water quality, can be dangerous to public health, or cause epidemics.

Clostridium perfringens, which is a sulphite-reducing anaerobic bacteria, can cause water quality to deteriorate as spores can survive in the water for a long time and can withstand disinfection. Removal from the water is possible by filtration. Their presence in drinking water refers to errors in the filtration procedure.[15]

Coliform bacteria are the genera of the lactose lactose at $30 \mathrm{oC}$ (Klebsiella, Enterobacter, Citrobacter, Escherichia) of the Enterobakteriaceae family, which are members of the normal intestinal flora of animals. If they occur in food, the possibility of contamination of the faeces occurs. [16]

Coliform bacteria are found in wetlands, soil and vegetation; and are generally present in large numbers in the faeces of warm-blooded animals. While these bacteria alone do not cause serious disease, their presence indicates that other fecal pathogens may be present. When coliform bacteria enter the human body, they cause diarrhea and vomiting. [15][17]

General information on the presence of faecal contamination and safely detectable bacteria (eg Escherichia coli) is available for water contamination. These bacteria are found in the intestinal tract of humans and animals, where they form part of the aerobic, facultative anaerobic normal bacterial flora and are essential for digestion.

Most E.coli strains are harmless, but some strains cause pathogens and diarrhea.[18] Other typical symptoms of the disease are abdominal cramps, sudden watery diarrhea, occasionally bloody, and sometimes nausea, vomiting and fever. Most patients recover within one or two weeks.[18]

Although Escherichia coli itself can be a pathogen, it is not usually the bacterium itself that poses a health risk, but its appearance in the water means that the water in question has recently been contaminated with faeces. In this case, bacteria that cause certain diseases (typhoid, cholera, dysentery) are also attempted.[4]

The number of bacteria growing at $22^{\circ} \mathrm{C}$ provides information on the general bacterial contamination of the water network and the state of the network and drinking water to support bacterial growth. The high number of colonies is usually the result of post-proliferation in the water network. It can also contribute to corrosion of the network, water stagnation or high organic matter content of raw water. Originally a large number of colonies are also present in areas where the temperature of the raw water is permanently high. The $22{ }^{\circ} \mathrm{C}$ colony number 
is given by non-human environmental bacteria with no significant health risks. Indicator of bacteria indicates that the conditions in the water system allow bacteria to multiply. In the case of an increase in the number of colonies, the primary solution is to sponge the net to remove mineral or microbial deposits.[15]

Pseudomonas aeruginosa and Legionella must be a problem for public health. Pseudomonas aeruginosa is found in soil, water, wastewater and faeces. It is not suitable as a faecal indicator because of its tendency to reproduce on the surface of organic matter in contact with water and water. Risk of infection through bodily injury, wounds, or inhalation. Its presence refers to the deterioration of the microbiological quality of the water.[14]

The Legionella is a genus commonly found in aqueous media. More than 50 species are known, of which at least 20 can be human pathogens. The infection is not caused by water absorption but by inhalation of water spray containing Legionella (eg during showering or rinsing the toilet). It is generally not dangerous for a healthy person, but rather a health risk for weakened immune systems. Can proliferate in any built-in aqueous environment with slow flow or stagnant water at temperatures between $20-55^{\circ}$ C.[14]

The disease-causing bacteria are the Vibrio and Shigella species. Millions of deaths caused by Vibrio cholera have died in the past, but infection is still common in some countries. The source of the infection is drinking water contaminated with faeces, the water that has been soaked and washed. Cholera is one of the fastest developing diseases. The bacterium produces enterotoxin, which destroys ion transport in the intestinal epithelium, and consequently dehydrating diarrhea may occur. Mortality rate without adequate therapy is very high, 20$60 \%$.[19]

In the genus Shigella, four species are distinguished, which are pathogens of the haemostasis. In Hungary, Shigella sonnei is the most common. It spreads directly or indirectly (from food, water, feces) from man to man with an infectious disease associated with diarrhea, bloody bowel movements, and analgesia. In general, spontaneous healing occurs within 3-5 days, but in infants and malnourished adults, dysentery can be fatal.[18]

The microbiological characteristics listed and the associated limit values can be found in Table 1. It can be seen that there is no present limit of Esherichia coli, Enterococcus bacteria, Pseudomonas aeruginosa, or the limit of 0 for enteric or other pathogenic microorganisms.

\begin{tabular}{|c|c|c|}
\hline Test characteristic & Limit & Regulation \\
\hline Escherichia coli (E.coli) & $0 / 250 \mathrm{ml}$ & \multirow{5}{*}{$\begin{array}{l}\text { 201/2001. (X. 25.) } \\
\text { government decree }\end{array}$} \\
\hline Enterococcus & $0 / 250 \mathrm{ml}$ & \\
\hline Pseudomonas aeruginosa & $0 / 250 \mathrm{ml}$ & \\
\hline Number of colonies at $22^{\circ} \mathrm{C}$ & $100 / \mathrm{ml}$ & \\
\hline Number of colonies at $37^{\circ} \mathrm{C}$ & $20 / \mathrm{ml}$ & \\
\hline Legionella & $\begin{array}{l}\text { different levels of risk } \\
\text { management measures }\end{array}$ & $\begin{array}{l}\text { 49/2015. (XI.6.) EMMI } \\
\text { decree }\end{array}$ \\
\hline $\begin{array}{l}\text { Other pathogenic } \\
\text { microorganisms (eg Shigella, } \\
\text { Salmonella, Vibrio) }\end{array}$ & $0 / 5000 \mathrm{ml}$ & MSZ 450/1-1989 \\
\hline
\end{tabular}

Table 2 Limit values for microbiological water quality characteristics. [20] 


\section{Viruses}

Detecting and testing viruses from water is much more difficult than bacteria. In addition, the situation is complicated by the fact that the regulations in force in Hungary do not contain mandatory tests or limit values. In waters, viruses can survive for a long time (3-10 months) and are highly resistant, with only strong disinfectants inactivated. The most common viruses in water are: Hepatitis A, Calicivirus, Rotaviruses.[18]

Hepatitis A is the most well-known pathogen among water-borne viruses. The main source of infection is the inadequate hygiene level or inadequate quality of drinking and wash water. When eating food, it is advisable to take care not only of raw vegetables and fruits, but also of all raw foods, in order to reduce the risk of infection. It causes one or two weeks of illness with jaundice and malaise. The virus is excreted by the stool of the patient.

Diseases caused by calicivirus noroviruses (Norwalk viruses) are the second most common viral infections after rhinitis. They cause gastrointestinal infectious disease.[18]

Globally, rotavirus infection causes the majority of vomiting and diarrhea diseases among children and infants. In more severe cases, it may cause dehydration. The incubation time is usually 2 days. Water is the source of the infection, but the frequency of contact is also high. Often this causes a disease called diarrhea in travelers. The danger is that high levels of water loss result in milder or more severe dehydration, or even life-threatening conditions.

\section{Other biological risks}

About protozoa, or animal monocytes, the source of infection is water contaminated with faeces. Infected people may experience headache, vomiting, diarrhea and dehydration. Preventing personal and environmental hygiene regulations and avoiding faecal contamination of water is important in their prevention.

Of the worms, the human body is infected by water through cylindrical or tapeworms. Their presence may mean external contamination, technical problems in the water network, cracking, inadequate fitting of pipe fittings. Usually they are not parasites, but they can become infectious agents with their unicellular pathogens. Fortunately, their incidence in drinking water is very rare.[19]

Cyanobacteria, or more commonly known as blue algae, are closely related to bacteria. The structure of their cells is basically the same as that of the bacteria, but they have no whiplike forms. Their toxic variants are also known, which can cause liver inflammation. They can overgrow in hot weather and cause water blooms. [21]

Iron-Manganese Bacteria the most common living entity in drinking water. Growing in the network causes yellowish-brown discoloration of the water, and has a taste and odor. They also play a role in corrosion and corrosion processes. They originate from surface waters and waters offshore. They have a taste, smell and color.

Fungi can also occur in surface water and in wastewater. Their occurrence in drinking water indicates technological deficiencies and deterioration. Fungus spores can be water quality degrading. They are harmful to health when they produce different toxins.[14]

From the above it can be seen that the infection of waters is basically caused by viruses, bacteria, fungi, protozoa, which are relatively fast mutated, usually with high resistance, and are often resistant to previously proven methods of protection. Their impact depends largely on the age of the consumer, the nutrition, and the resistance of the body. The spread of the infection is related to the stakeholders and the compliance with the epidemiological rules..[22] For the quality of drinking water quality, the protection of water basins, water extraction sites, and the treatment of extracted raw water by various disinfectant methods play an important role:

- disinfectant dosing or chlorination that kills microorganisms,

- UV irradiation, inactivates microorganisms, 
- ultrafiltration, nanofiltration removes microorganisms,

- natural biological screening that removes the living environment of microorganisms by extracting organic matter.

It is clear from the list that biological screening has the most advantageous properties. Recent research has also shown that natural coastal screening may not only be effective against bacteria but also against viruses.[22] In recent years, the adverse effects of extreme weather events as a result of global climate change are also a threat to water bases. [24] The amount of precipitation that falls during the flood-like rain cannot be led by the sewer network, the water appearing in a given area is congested and forms a coherent water surface as inland water. The problem is particularly severe in places where no separate rainwater drainage system has been built, but rainwater also flows into the sewage system. Here, in the event of saturation, rainwater mixed with waste water enters the environment, which poses a risk of infection outside the human environment as regards the elements of the water supply system.

\section{SUMMARY}

Nowadays, special attention should be paid to the issue of sustainable water management, which, among other things, guarantees that drinking water of adequate quality is supplied to consumers. The water utility service is an element of the critical infrastructure, so the various processes must be carried out with due care. The first and most important step is the protection of the water base, for which there is no uniform specification, but it is definitely one of the most important factors in water extraction and drinking water supply. With adequate mechanical protection of the water bases, it is possible to prevent any dirt from entering the water.

Examining the types of water pollution and the most frequent threats to water bases, it can be stated that infections are usually caused by biological threats, such as bacteria, viruses, protozoa, fungi, worms. In my writing, I described these risk factors of biological origin, presenting the most common types, as well as the limits set by the laws, standards and specific tests.

I found it important to demonstrate the proper protection of water bases and the regular inspection and control of waters, since the consumption of water contaminated water has a negative impact on human health, as it can lead to the development of diseases, infections and even epidemics. The choice of disinfection procedures is always determined by the way, time, size of the infection and the population of the affected area. With my research results, I wanted to help the work of the water protection professionals.

\section{REFERENCES}

[1] RAKONCZAY Z.: Környezetvédelem, Budapest: Szaktudás Kiadó Ház, 2004.

[2] RAJNAI Z., RAJNAI T.: A viz és Magyarország, Budapest, 2012

[3] PREGUN CS., JUHÁSZ CS.: Vizminőségvédelem, Debreceni Egyetem Agrár- és Gazdálkodástudományok Centruma (AGTC), 2010.

[4] FÖLDI L., HALÁSZ L.: Környezetbiztonság, Complex Kiadó Kft. Budapest, 2009

[5] MÁDLNÉ SZŐNYI J.: Hidreológia. Budapest: ELTE, 2013. (elektronikus egyetemi jegyzet) http://tktamop.elte.hu/sites/ttktamop.elte.hu/files/tananyagok/hidrogeologia.pdf (downloaded: 2018. 11. 02.) 
[6] SCHMOLL, O., HOWARD, G., CLINTON, J., CHORUS, I.: Managing the Quality of Drinking-water Sources in Protecting Groundwater for Health. London: World Health Orga-nization, 2006. www.who.int/water_sanitation_health/publications/PGWsection1.pdf (downloaded: 2018.11.02.)

[7] BODÁNÉ KENDROVICS R.: Vízminőség-védelem gyakorlati oktatási metodika fejlesztése a müszaki felsőoktatásban. Sopron: Nyugat-magyarországi Egyetem, 2012. (Doktori értekezés)

[8] 1995. évi LVII. törvény a vízgazdálkodásról

[9] TAKÁCS K., KUTI R.: Fenntartható vízellátás biztosításának aktuális kérdései. Védelem Tudomány, Katasztrófavédelmi Online Tudományos Folyóirat II 2 (2017) 304-317.o.

[10] 2080/2008. (VI. 30.) Kormány határozat a Kritikus Infrastruktúra Védelem Nemzeti Programjáról.

[11] 123/1997. (VII. 18.) Korm. rendelet a vízbázisok, a távlati vízbázisok, valamint az ivóvízellátást szolgáló vízi létesítmények védelméről

[12] KALUZSA A., KUTI R., BEREK T.,: Biztonsági szempontok a vízellátásban, Müszaki Katonai Közlöny XXVIII. /2. 2018, pp. 307-316. http://hhk.archiv.uninke.hu/downloads/kiadvanyok/mkk.uni-nke.hu/PDF 2018 2sz/PDF 2018 2sz.pdf (downloaded: 2018. 12.05.)

[13] 201/2001. (X.25.) Kormányrendelet az ivóvíz minőségi követelményeiröl és az ellenőrzés rendjéről.

[14] DÁVIDOVITS ZS.: A lakossági ivóvízellátás környezetbiztonsági kockázatai csökkentésének lehetőségei és az ivóvízbiztonsági tervezés kapcsolatrendszere. Budapest: Nemzeti Közszolgálati Egyetem, 2015. (Doktori értekezés)

[15] ORSZÁGOS KÖZEGÉSZSÉGÜGYI KÖZPONT: Ivóvíz kiskáté, lakossági tájékoztató a gyakran ismételt kérdésekről, 2016. http://oki.antsz.hu/files/dokumentumtar/kiskate2016-03.pdf (downloaded: 2018.12.05.)

[16] BÍRÓ G.: Élelmiszer-higiénia. Agroinform Kiadó. 2014. 668.o.

[17] ÁLLAMI NÉPEGÉSZSÉGÜGYI ÉS TISZTIORVOSI SZOLGÁLAT Országos Tisztiorvosi Hivatal Kommunikációs Főosztály Közlemény, 2010. http://www.katasztrofavedelem.hu/letoltes/lakossag/antsz_vorosiszap_info.pdf (downloaded: 2018.12.15.)

[18] DEÁK T.: Élelmiszer- Mikrobiológia. Mezőgazda Kiadó. 2006. 382.o.

[19] BALLA CS., SIRÓ I..: Élelmiszer-biztonság és-minőség I.. Mezőgazda Kiadó, 2007.

[20] KRETZ A.: Az ivóvízkészlet- szennyezés fajtái, különös tekintettel a biológiai szennyeződésekre. Műszaki Katonai Közlöny, XXVIII 2 (2018) 146-158. o.

[21] TURCSÁNYI G.: Növénytan. Budapest: Szaktudás Kiadó Ház, 2005.

[22] KUTI R., GRÓSZ Z.: Biológiai eredetű veszélyhelyzetek kezelése, előtérben a mentesítési feladatok, HADMÉRNÖK XI./1. 2016, pp. 125-132. http://www.hadmernok.hu/161_13_kutir_gz.pdf (downloaded: 2018.12.15.) 
[23] MÁTTYUS S.: Vízellátás. Budapest: General Press, 2008.

[24] R. KUTI, Á. NAGY: Weather Extremities, Challenges and Risks in Hungary, ACADEMIC AND APPLIED RESEARCH IN PUBLIC MANAGEMENT SCIENCE 14./4. 2015, pp. 299-306. http://archiv.uni-nke.hu/uploads/media_items/aarms-vol-14_issue4 -2015.original.pdf (downloaded: 2018. 12. 15.) 